\title{
Explanatory Factors for the Uneven Implementation of Charter School Policy*
}

\author{
Jeongho (John) Lee ${ }^{* *}$ and JinWoo Jeong***
}

\begin{abstract}
Charter schools are regarded as the fastest growing and most impressive innovative institution in public education in Colorado. However, a charter school policy has been unevenly implemented across Colorado school districts. This study aims to clarify what conditions lead to this uneven implementation. To examine the efforts of Colorado school districts to innovate within the conventional public school system, it analyzes several hypotheses based on the diffusion model and socioeconomic factors with an ordinary least squares regression model. Statistical analysis demonstrates that three predictor variables-diffusion, educational level, and alternative innovation-positively influence the social phenomenon that each Colorado school district shows different efforts in the implementation of charter school policy. Among them, the number of alternative schools is the strongest regressor, and the existence of neighboring school districts with charter schools is the second strongest regressor that exerts powerful effects to account for the wide variance in the implementation of Colorado school districts' charter school policy.
\end{abstract}

Keywords: Colorado, charter school policy, diffusion, socioeconomic factors

\section{INTRODUCTION}

Improvement of public educational achievement has long been a priority for people and organizations involved in public education. For this, a new approach, school choice, was emphasized in Chubb and Moe's remarkable book (1990), which points out that the monopolistic characteristics and direct control common in the conventional

\footnotetext{
* This work was supported by the Inje Research and Scholarship Foundation in 2010.

** Jeongho (John) Lee is an ABD in the School of Public Affairs at the University of Colorado Denver. E-mail: Jeong.Lee@ucdenver.edu.

*** JinWoo Jeong, corresponding author, is an associate professor in the Department of Public Administration, Inje University. E-mail: jw0611@inje.ac.kr.
}

Manuscript received October 10, 2011; out for review October 17, 2011; review completed January 3, 2012; accepted January 15, 2012.

The Korean Journal of Policy Studies, Vol. 27, No. 1 (2012), pp. 153-172.

(C) 2012 by the GSPA, Seoul National University 
public schools (CPS) system are not enough to satisfy parents eager to improve their children's achievement. To reduce the monopolistic characteristics of the CPS system and offer better services to educational customers, school choice scholars propose several innovative institutions: alternative schools, charter schools, home schooling, magnet schools, open enrollment laws, and vouchers.

We can find main rationales of the school choice movement at a fact that conventional public schools' performance is getting weaker. Hess (2008) points out that the United States did not achieve good ranks in math and science in the 2006 Program for International Student Assessment (35th in math and 29th in science among 57 industrialized countries). The school choice movement starts from the view that the CPS system is not accountable, and promotes market-oriented reforms by arguing that the command-and-control system has not effectively improved public educational achievement (Buckley \& Schneider, 2007; Chubb \& Moe, 1990; Stoddard \& Corcoran, 2007).

School choice advocates argue that market-oriented reforms can improve public schools' performance through a competitive environment, which is contrasted with the bureaucratic environment of the CPS system (Schneider, Teske, \& Marschall, 2000). They explain that competition encourages public schools to seek innovative ways to satisfy their customers (Stoddard \& Corcoran, 2007). That means that public schools' services can be more improved to come up with the satisfaction and demand of customers. Their reasoning is aligned with public choice advocates (Buchanan \& Tullock, 1962; Hodge, 2000; Weimer \& Vining, 1999, 2005), who argue that increased competition can improve organizations' performance through a mechanism that offers more services for rational customers.

Especially, this article targets charter schools among aforementioned educational innovations that emphasize competitive circumstances. Charter schools based on market oriented reforms in the conventional public education area have rapidly spread from state to state since Minnesota passed its Charter School Law in 1991 (Buckley \& Schneider, 2007; Mintrom, 2000; Schneider, Teske, \& Marschall, 2000; Stoddard \& Corcoran, 2007; Vergari, 2002). Presently, 40 states and the District of Columbia have adopted a charter school law (Renzulli \& Roscigno, 2007).

Many public policy scholars (Mintrom, 1997, 2000; Mintrom \& Vergari, 1998; Renzulli, 2005; Renzulli \& Roscigno, 2005; Wong \& Langevin, 2007; Wong \& Shen, 2002) have sought to explain the variance in the formation of charter school laws among states. However, until now there has been little focus on the local level, which is where education policy is implemented. Research related to school choice at the state level also usually focuses on policy adoption using event history analysis or a binary logistic regression model. This kind of research only tests simple social phenomena 
with a dichotomous characteristic — the fact that some states adopt some school choice policies while others do not.

This study empirically examines the more complicated social phenomena of local policy implementation, in which local government entities-including cities, counties, and school districts - unevenly carry out policies formulated by the state or federal government. It finds meaningful explanatory factors that affect the uneven implementation of Colorado school districts' charter school policy.

The next section of this article provides an overview of charter schools across the United States and particularly in Colorado. This is followed by a literature review, presentation of hypotheses, and a description of the research design. Analysis results are then described and analyzed, and further research steps are proposed.

\section{CHARTER SCHOOLS}

The CPS system has frequently used top-down and command-and-control management styles. However, many studies show that this approach is not effective for improving students' achievement because it can discourage schools' use of outside resources that improve and change conventional public schools. To overcome the inefficient structure of the CPS system, school choice scholars argue that it should be made more competitive by emphasizing market-driven concepts and introducing atypical institutions such as alternative schools, charter schools, home schooling, magnet schools, open enrollment laws, and a voucher system (Chubb \& Moe, 1990; Schneider, Teske, \& Marschall, 2000).

The concept of charter schools was introduced in the United States by Ray Budde and Albert Shanker in the late 1980s (Vergari, 1999, 2002). Their idea came to fruition in Minnesota's 1991 Charter School Law. Other states followed suit, and 41 jurisdictions including Washington, D.C. currently have charter school laws (Renzulli \& Roscigno, 2005; Vegrari, 2007; Wong \& Langevin, 2007). The charter school movement has been described as an educational reform that effectively facilitates public educational performance without weakening functions and roles of public education. The charter school movement is possible due to its two benefits: it provides students and parents as customers with greater opportunities to improve students' performance (Schneider, Teske, \& Marschall, 2000), and it gives public schools more chances for innovation by providing students chances to transfer to a charter school (Vergari, 2002).

Buddin and Zimmer (2005) define charter schools as "publicly funded schools that operated outside the direct control of conventional school districts and are under the 
authority of a quasi-contract, or charter granted by a public body" (p. 351). The charter school is unique in terms of its fiscal situation and autonomy, different from both conventional public schools and private schools.

Charter schools are established by individuals, groups, or organizations that are concerned about CPS performance (McGuinn, 2003). Interest groups establish and manage charter schools, and sponsors such as school districts and independent institutions supervise them to ensure that they adhere to their charters (Vergari, 2002). Mintrom and Vergari (1997) and Renzulli and Roscigno (2005) explain that the organizers might be teachers, parents, or others interested in charter school establishment, and the authorizer might be a school district, state department of education, or other public authority. Charter school advocates argue that a charter school is a primary way to introduce more innovative tools in the CPS system by fostering public school competition and accountability and improving school performance (Schneider, Teske, \& Marschall, 2000; Stoddard \& Corcoran, 2007).

More than a million pupils are enrolled in about 3,600 US charter schools in 41 jurisdictions (Kirst, 2007). The growth of charter schools across America is remarkable compared to other reforms in public education. The Center for Education Reform (2006) characterizes 18 of these laws as strong and 23 as weak. It considers Washington, D.C. to be the easiest jurisdiction in which to establish a charter school and Mississippi to be the most difficult, and evaluates Colorado, the focus of this study, to have the eighth strongest law.

The Colorado Charter Schools Act was signed by then Governor Roy Romer with bipartisan support in 1993 (Lee \& Kim, 2010; Ziebarth, 2005). Since then, charter schools have spread widely in Colorado. The first, called Academic Charter School and Connect School, were built in the Douglas County-RE 1 and Pueblo school districts that same year. In 2007, the number of charter schools in Colorado reached 140 and enrolled about 57,000 students (Lee \& Kim, 2010). In Colorado, either a school district or the Charter School Institute can authorize a charter school. Of 178 school districts in the state, 45 school districts operate at least one charter school, and charter schools make up about 7 percent of Colorado's K-12 public schools (Carpenter \& Kafer, 2009).

In 2007, Denver County 1 school district had 20 charter schools, and Jefferson County R-1 operated 15 (Colorado Department of Education, 2007). Ziebarth (2005) points out that many of Colorado's charter schools are situated in rural areas, compared to other states, although the two districts mentioned above, Denver County 1 and Jefferson County R-1, are located in an urban and suburban area respectively. Another way in which Colorado differs from the national trend is that the majority of its charter school students are Caucasian (Lee \& Kim, 2010; Ziebarth, 2005). ${ }^{1}$ 
Like other states' Charter School laws, the Colorado Charter School Act, enacted in 1993, establishes accountability for charter schools. Accountability is a main rationale for the authorization of charter schools. Colorado's charter schools are required to join the Colorado Student Assessment Program, which measures students' reading, writing, and math skills (Lee \& Kim, 2010). A recent comparison of assessment results from 1996 to 2004 (Ziebarth, 2005) found the performance of charter schools to be higher than that of conventional schools at the elementary and middle school levels.

Many Coloradans welcome charter schools, and their growth has gradually increased. This helps Colorado's local governments to energetically pursue the school choice movement. Therefore, Colorado offers a good opportunity to research why school districts unevenly implement their charter school policy.

\section{FACTORS INFLUENCING THE UNEVEN IMPLEMENTATION OF THE LOCAL CHARTER SCHOOL POLICY}

Charter school policy has been considered a fresh educational innovation that leads to changes in the monopolistic CPS system and provide customers - students and their parents - with better public educational services (Mintrom, 2000; Schneider, Teske, \& Marschall, 2000; Vergari, 2002). Klingner (2006) emphasizes that the emergence of innovative policies requires "processes of adaptation, anticipation and openness to change" (p. 61). This suggests that policy actors consider the necessity of their own changes by some environments. Namely, his remarkable view accounts for that the formation and implementation of these innovative policies are affected by various factors surrounding policy actors. Klingner (2006), building on earlier work (Julnes \& Holzer, 2001; Landry, Lamari, \& Amara, 2003; Webber, 1987), introduces 24 factors in five categories - political, organizational, social/interaction, technical, and humanthat help explain why policy actors formulate and implement innovative policies. This perspective can be extended to a research question such as under what conditions policy actors want and need to change themselves. Many scholars have studied the process of innovative policies utilizing this basic research question.

To apply this perspective to the educational policy process, this study developed two categories - the diffusion phenomenon (Rogers, 1962; Berry \& Berry, 1990, 1999, 2007; Walker, 1969) and socioeconomic factors (Mintrom \& Vergari, 1998; Schneider, Teske, \& Marschall, 2000) — in an attempt to understand why Colorado

1. Ziebarth (2005) reports that Caucasian students make up 68 percent of Colorado's charter school students and 64 percent of the students in conventional public schools. 
school districts widely vary in the implementation of a charter school policy.

\section{Diffused Phenomenon}

The diffusion model developed by Rogers (1962) and Walker (1969) helps test and explain the mechanism by which organizations adopt and operate innovative institutions. Developing this model, Walker's two main questions are: “(1) why do some states act as pioneers by adopting new programs more readily than others, and once innovations have been adopted by a few pioneers, (2) how do these new forms of service or regulations spread among the American states?" (p. 881). The diffusion model provides this study with a hypothesis related to emulation in Colorado charter schools.

Walker's view emphasizes emulation of policy actors who have already experienced positive outcomes from innovative institutions. That is, when states or counties adopt and operate institutions, competition, imitation, and learning encourage them to follow other states or counties that have already successfully established such institutions (Berry \& Berry, 1999, 2007). Berry and Berry (1990) have used the diffusion model to find determinants in the adoption of specific institutions, such as a lottery and new laws, across states. They demonstrate that states adopt and implement institutions by emulating other states that have already implemented the same or similar institutions. They also more deeply categorize the diffusion model into diverse styles, such as the national interaction, regional diffusion, leader-laggard, and vertical influence models.

This study tries to integrate Berry and Berry's regional diffusion model with the mimetic isomorphism model proposed by DiMaggio and Powell (1983). As Frederickson, Johnson, and Wood (2004) have pointed out, the diffusion and isomorphism concepts are similar. This study starts from the basic idea of the diffusion model—policy actors (individuals or organizations) emulate other policy actors that are geographically proximate (Berry \& Berry, 1999, 2007) — which is similar to the mimetic isomorphism proposed by DiMaggio and Powell. ${ }^{2}$ Both political scientists and sociologists postulate that when organizations face new or uncertain tasks and situations, they mimic other organizations that have successful institutions (Rivera \& deLeon, 2004; Rivera,

2. Scholars explaining isomorphism (DiMaggio \& Powell, 1983; Meyer \& Rowan, 1977; Powell \& DiMaggio, 1991) insist that organizations change by mimicking other organizations that have already successfully dealt with similar uncertainty or difficulty. Isomorphism is classified into three types: coercive, mimetic, and normative. In coercive isomorphism, organizations respond to pressure from higher-ranking organizations. In normative isomorphism, they evolve by adapting moral or professional norms that are proposed and supported by professional associations. In mimetic isomorphism, the type focused on in this study, they learn from successful organizations. 
deLeon, \& Koerber, 2006). This helps to minimize internal conflict as well as errors, which may have substantial influence on the organization's survival (Powell \& DiMaggio, 1991).

Diffusion usually happens for a reason; for successful institutions in other jurisdictions, jurisdictions learn, adopt, and implement them from other jurisdictions by the functions of competition or imitation. Decision makers are influenced by requests from their own citizens who want to operate the institutions that have been successfully operated in other jurisdictions. The diffusion model suggests that one determinant that allows a jurisdiction to adopt and operate institutions is the existence of neighboring jurisdictions that have already experienced the same or similar institutions. DiMaggio and Powell's idea, represented as contagion and mimicry, explains that organizations that are near to organizations that adopt and implement new institutions find it easier to be exposed to new institutions (Renzulli \& Roscigno, 2005). Thus, variations in the spread and operation of new institutions can be shown to be influenced by the existence of neighboring organizations or jurisdictions that already operate new institutions.

Both concepts, regional diffusion and mimetic isomorphism, can help explain why Colorado's school districts vary in their implementation of charter school policy. Based on these models, this study assumes that the probability that a school district will establish more charter schools will be increased if neighboring school districts already operate charter schools. Therefore, it is predicted that school districts adjoining districts that already operate charter schools are more likely to implement charter schools themselves - and that such emulation is a driving force in the variation in the implementation of a charter school policy.

\section{Socioeconomic Factors}

Ostrom $(1999,2007)$ and Mazmanian and Sabatier (1980) indicate that the characteristics of communities or organizations influence the outcomes of their actions. That is, the institutions formulated and implemented by policy actors (communities or organizations) are best understood by investigating their needs and resources, which are usually measured by socioeconomic characteristics. This study makes hypotheses based on three socioeconomic factors-fiscal situation, educational level, and poverty-in 178 school districts in Colorado.

The fiscal situation of each jurisdiction plays a vital role as a predictor variable. Portz (1996) argues that financial support from city and state has been a key promoter of educational reform. Mintrom and Vergari (1998) also argue that there is a positive relationship between high state expenditures and outcomes of innovative educational institutions, because high-spending states apparently pay more attention to exploring 
different potential educational innovations. This means that more wealthy school districts are more likely to implement innovative educational institutions, because their healthy finances support their capacity to create structural changes. Thus, it is expected that school districts' financial situation is a factor in determining whether they operate charter schools. A hypothesis for this assumption is that school districts with a healthier financial situation are more likely to implement a charter school policy.

Schneider, Teske, and Marschall (2000) argue that highly educated parents can get better information about schools by forming and managing their own networks. This explanation shows that it is possible that school districts with more highly educated residents receive more requests for public school reforms. Thus, school districts with a greater percentage of people with a master's or higher degree are more likely to implement a charter school policy.

Jurisdictions whose residents have a higher economic level can not escape multiple demands from their residents (Berry \& Berry, 1999, 2007). Schneider, Teske, and Marschall (2000) prove that higher-income parents can more easily get information about schools and school innovations than poor families can. Chubb and Moe (1990) argue that parents and other residents who have better information about schools can demand more school innovations from their government. Therefore, school districts with a lower poverty rate are more likely to implement a charter school policy.

\section{Control Variables}

This study uses two variables, which might influence Colorado school districts' uneven implementation of educational innovations, as control variables: student rate, and the existence of other similar educational innovations. Some scholars (Walker, 1969; Wong \& Langevin, 2007) demonstrate that jurisdictions want to change through innovative institutions when their capacity - the number and quality of employees - is poor. Poor capacity is an obstacle to delivering better public services. In the educational area, Wong and Langevin's (2007) study proves that high student's rate (low teacher's rate) - a proxy of school district capacity-has a positive effect on the formation of states' charter school laws. Their research suggests that lack of capacity in a jurisdiction is positively related to the consideration and operation of educational innovations. Therefore, it is predicted that school districts with higher student rates are more likely to implement a charter school policy to overcome the limits of the CPS system and offer more qualified education services.

Renzulli (2005) proves that the presence of similar educational innovations, such as open enrollment or private schools, increases the probability that a state will enact a charter school law. She argues that a reason that states formulate charter school laws is 
that decision makers or voters have already been embedded in other educational innovations-alternative schools, ${ }^{3}$ home schooling, magnet schools, open enrollment laws, or vouchers-without strong resistance. ${ }^{4}$ Thus, it is predicted that the existence of other forms of public educational innovation is more likely to increase the variance among school districts' implementation of a charter school policy. Among the aforementioned innovations, the number of alternative schools in each school district is used to estimate this variable.

\section{RESEARCH DESIGN}

The primary research question is as follows: What factors drive Colorado school districts' uneven implementation of charter school policy? To answer this question, this study looks at the relationships between the number of each school district's charter schools and key explanatory variables related to the diffusion phenomenon and socioeconomic factors. The study is based on secondary data obtained from the Colorado Department of Education. Six regressors including two control variables are used to analyze the research question. The study tests the following hypotheses:

Hypothesis 1 (diffusion): School districts with neighbor districts that already have charter schools are more likely to implement their own charter school policy. This study establishes a dummy variable by giving a school district a score of 1

3. Alternative schools treat troubled students who are in educational failure due to removal from a conventional school (Carver, Lewis, \& Tice, 2010). An alternative school may have a short- or long-term program. Alternative schools with short-term programs, which are called community schools, let students return to their original school if their academic capacity or behavior improves. In alternative schools with a long-term program, which are called continuation schools, students learn job-related skills and remain in the school through graduation. A long-term program usually focuses on students at the high school level (Gurantz, 2010; Hill, 2007).

4. Renzulli's idea is supported by the open-natural system models-population ecology, resource dependence, and sociological neo-institutionalism. Scholars in the open-natural models argue that the preexistence of similar institutions helps policy actors-individuals or organizations - formulate and implement new institutions. That is why policy actors are embedded in the effects and legitimacy of similar institutions and are inclined to take the acceptance of new institutions for granted due to their embeddedness in similar institutions. Note: Representative proponents of the open-natural models include Howard E. Aldrich, Paul J. DiMaggio, John Freeman, Michael T. Hannan, John W. Meyer, Jeffrey Pfeffer, Walter W. Powell, Brian Rowan, and Gerald R. Salancik (Rainey, 2003; Scott, 1998). 
if it has at least one neighboring school district operating charter schools already and 0 if it does not.

Hypothesis 2 (fiscal situation): School districts with a healthy fiscal situation are more likely to implement a charter school policy. This study uses an annual average of teacher salary as a proxy for a school district's financial condition. ${ }^{5}$

Hypothesis 3 (educational level): School districts with more educated residents are more likely to implement a charter school policy. This variable is measured by the percentage of residents with a master's or higher degree in each school district.

Hypothesis 4 (poverty): School districts with a higher poverty rate are less likely to implement a charter school policy. The percentage of residents below the poverty line in each school district is utilized to measure this variable.

Hypothesis 5 (student rate): School districts with more students per teacher are more likely to implement a charter school policy. This variable is estimated by dividing the total number of students by the total number of teachers in each school district.

Hypothesis 6 (alternative innovation): School districts with other innovative types of schools are more likely to implement a charter school policy. The number of alternative schools in each school district is used as a proxy of this variable.

In this study, the units of analysis are 178 school districts in Colorado. Table 1 shows the potential influence of each independent variable and summarizes the method of measurement described above. The statistical technique used to test this study's hypotheses is an ordinary least squares (OLS) regression model summarized in the following equation:

$$
N C H S=\beta_{0}+\beta_{1} D I F F+\beta_{2} F I S I+\beta_{3} E D L E+\beta_{4} P O V E+\beta_{5} S T R A+\beta_{6} A L I N+e
$$

where NCHS=number of charter schools in a district, DIFF=diffusion, FISI=fiscal

5. In the United States, school districts are funded by a variety of taxes-local ownership tax, local property tax, state sales tax, and state income tax. School districts usually decide teacher salaries in their territory on the basis of their annual fund each year (Basilico et al., 2002). That means that if an annual average of teacher salary of a school district is higher than other school districts, the school district's financial situation is better than other school districts.' Thus, an annual average of teacher salary can be a proxy to estimate each school district's fiscal situation. 
situation, EDLE=educational level, POVE=poverty, STRA=student rate, and ALIN= alternative innovation.

Table 1. Predicted Influence of Regressors on Implementation of a Charter School Policy

\begin{tabular}{l|l|c}
\hline All regressors & \multicolumn{1}{|c}{ M easurement } & Predicted influence \\
\hline Diffusion & Existence of neighboring school district with charter schools & positive \\
\hline Fiscal situation & Average annual teacher salary & positive \\
\hline Educational level & Percentage of residents with a master's or higher degree & positive \\
\hline Poverty & Percentage of people below the poverty line & negative \\
\hline Student rate & Total number of students divided by total number of teachers & positive \\
\hline Alternative innovation & Number of alternative schools & positive \\
\hline
\end{tabular}

\section{RESULTS OF STATISTICAL ANALYSIS}

Descriptive findings for all variables are shown in table 2. The number of charter schools in Colorado school districts ranges between 0 and 20. A school district with 20 charter schools is Denver County 1 (Colorado Department of Education, 2007). Of 178 Colorado school districts, 16 percent have neighboring school districts that operate charter schools earlier. On average, there is one teacher for about every 14 students. The average teacher salary is about $\$ 38,068$. Nearly 26 percent of people over 25 years old in each school district have a master's or higher degree. On average, about 9 percent of people are below the poverty line. The number of alternative schools in each district ranges between 0 and 11 with an average of 0.43 .

Table 2. Descriptive Analysis of Variables

\begin{tabular}{l|c|r|r|r|r}
\hline & $\mathrm{N}$ & Minimum & Maximum & Mean & Std. Deviation \\
\hline Charter schools & 178 & 0 & 20 & 0.70 & 2.172 \\
\hline Diffusion & 178 & 0 & 1 & 0.16 & 0.370 \\
\hline Fiscal situation & 178 & 14,210 & 54,651 & $38,068.45$ & $5,789.358$ \\
\hline Educational level & 169 & 0 & 14 & 3.88 & 2.730 \\
\hline Poverty & 171 & 1.2 & 24.1 & 8.805 & 5.1751 \\
\hline Student rate & 178 & 5.6 & 79.6 & 13.861 & 5.9846 \\
\hline Alternative innovation & 178 & 0 & 11 & 0.43 & 1.104 \\
\hline
\end{tabular}


The results of the analysis are shown in tables 3 and 4 . Table 3 describes correlations and multicollinearity of independent variables. Leech, Barrett, and Morgan (2008) and Lee and Kim (2010) point out that the OLS regression model can yield statistically inaccurate results, due to a high correlation among predictor variables. Thus, it is important to check multicollinearity before testing the relationships between outcome variable and all regressors. Table 3 shows the correlation, tolerance levels, and variance inflation factors of predictor variables. Its results indicate that multicollinearity does not exist among the six regressors, by showing that the values of all regressors' correlations are lower than 0.5 , the values of their tolerance are higher 0.5 , and the values of their variance inflation factors are smaller than 5 . These results for multicollinearity mean that the regressors do not contain similar information. Thus, this study is free from the multicollinearity issue and can expect more accurate statistical results.

Table 3. Correlation Matrix of All Predictor Variables

\begin{tabular}{l|c|c|c|c|c|c|c|c}
\hline & DIFF & FISI & EDLE & POVE & STRA & ALIN & Tolerance & VIF \\
\hline DIFF & 1.000 & 0.419 & 0.159 & -0.278 & 0.202 & 0.352 & 0.756 & 1.323 \\
\hline FISI & & 1.000 & 0.399 & -0.389 & 0.344 & 0.363 & 0.594 & 1.682 \\
\hline EDLE & & & 1.000 & -0.315 & 0.070 & 0.140 & 0.800 & 1.251 \\
\hline POVE & & & & 1.000 & -0.262 & -0.042 & 0.762 & 1.312 \\
\hline STRA & & & & & 1.000 & 0.175 & 0.853 & 1.172 \\
\hline ALIN & & & & & & 1.000 & 0.800 & 1.250 \\
\hline
\end{tabular}

Note: DIFF=diffusion; FISI=fiscal situation; EDLE=educational level; POVE=poverty; STRA=student rate; ALIN=alternative innovation. VIF=variance inflation factor.

As shown in table 4, the results of the OLS regression show a chi-square of 96.298 with a $p$-value of 0.001 , indicating that the combination of the six regressors significantly predicts the outcome variable. An adjusted $\mathrm{R}^{2}$ of 0.773 suggests that the six independent variables explain about 77 percent of the variance in Colorado school districts' uneven implementation of charter school policy. Among the six independent variables, two (diffusion and alternative innovation) are statistically significant at the 0.01 level, and one (educational level) is statistically significant at the 0.1 level, while the rest are not significant. The three independent variables confirm that the positive directions predicted in the hypotheses are also right to the explanation for the wide variance in Colorado school districts' implementation of charter school policy.

Three independent variables have statistical significance for the wide variance in Colorado school districts' implementation of charter schools; the coefficient for diffusion is statistically significant with a t-ratio of 4.173 at the 0.01 level. Its coefficient, 
1.037, indicates that there is a positive relationship between the diffusion regressor and the outcome variable. This means that there is a likelihood that a school district will operate more charter schools if neighboring school districts have already operated charter schools. The coefficient for the educational level regressor is statistically significant with a t-ratio of 1.859 at the 0.1 level. Its coefficient, 0.062 , indicates that there is a positive relationship between the educational level regressor and the outcome variable. This means that an increase of one unit for the educational level regressor results in an expected increase in 0.062 of the outcome variable. Finally, the coefficient for the alternative innovation regressor is statistically significant with a t-ratio of 19.277 at the 0.01 level. Its coefficient, 1.592, indicates that there is a positive relationship between the alternative innovation regressor and the outcome variable. This means that an increase of one unit for the alternative innovation regressor results in an expected increase in 1.562 of the outcome variable.

However, other estimators are not statistically significant at the 0.1 level. These results support hypotheses 1,4 , and 5 and indicate that the three regressors have positive relationships with the variance in Colorado school districts' uneven implementation of charter schools. They prove that Colorado school districts that have neighboring school districts that are already operating charter schools, more highly educated residents, and more alternative innovations are more likely to implement a charter school policy. Among these three variables, the values of standardized coefficients demonstrate that

Table 4. Determinants for School Districts' Uneven Implementation of Charter School Policy

\begin{tabular}{l|c|c|c|c|c}
\hline \multirow{2}{*}{} & \multicolumn{2}{|l}{ Unstandardized coefficient } & Standardized coefficient & & \\
\cline { 2 - 6 } & $\mathrm{B}$ & $\mathrm{S} . \mathrm{E}$. & $\mathrm{Beta}$ & $\mathrm{t}$ & Sig. \\
\hline Diffusion*** & 1.037 & 0.249 & 0.176 & 4.173 & 0.000 \\
\hline Fiscal situation & $-5.419 \mathrm{E}-6$ & 0.000 & -0.014 & -0.300 & 0.765 \\
\hline Educational level* & 0.062 & 0.033 & 0.076 & 1.859 & 0.065 \\
\hline Poverty & -0.025 & 0.018 & -0.059 & -1.400 & 0.163 \\
\hline Student rate & -0.007 & 0.015 & -0.019 & -0.466 & 0.642 \\
\hline Alternative innovation*** & 1.562 & 0.081 & 0.792 & 19.277 & 0.000 \\
\hline Constant & 0.142 & 0.703 & & 0.202 & 0.840 \\
\hline $\mathrm{N}$ & 168 & & & & \\
\hline $\mathrm{F}(6,162)$ & $96.298 * * *$ & & & & \\
\hline Adjusted $\mathrm{R}^{2}$ & 0.773 & & & & \\
\hline
\end{tabular}

Dependent Variable: Numbers of charter schools in each Colorado school district.

$* * *$ significant at 0.01 level; $* *$ significant at 0.05 level; * significant at 0.10 level 
the alternative innovation variable is the strongest factor, and the diffusion variable is the second strongest, to account for the dependent variable.

\section{CONCLUSIONS AND IMPLICATIONS}

This article investigated why and under what circumstances Colorado school districts widely vary in the implementation of a charter school policy. To attain exact answers to this question, the study first applied the diffusion model. The diffusion model is usually shown in research relevant to agenda setting, policy formation, and decision making in the stages heuristic. However, our empirical study concretely proves that regional diffusion is critical for explaining the broad variance in Colorado school districts' implementation of charter school policy. This suggests that the regional diffusion model is a good fit for policy implementation research like some theoretical approaches-policy entrepreneurs, policy networks, and interest groups-, which are used to explain policy implementation as well as agenda setting and policy formation in the public policy process.

This article's contribution is to pursue the pluralism by integrating both political science's and sociology's concepts that embrace the diffused phenomenon. Namely, this study does not hesitate that policy actors' efforts for innovative institutions' application are acknowledged and supported by both academic areas: political science (Berry \& Berry, 1999, 2007; Rogers, 1962, 2003; Walker, 1969, 1981) and sociology (DiMaggio \& Powell, 1983; Powell \& DiMaggio, 1991). If scholars only utilize a specific discipline to analyze social phenomena, their studies might miss a chance to make hypotheses more concrete in order to account for social phenomena. Therefore, this pluralistic approach provided this study with more fruitful theoretical backgrounds to account for the research subject.

Another contribution of this article is to extend the scope of the study of charter schools from the state to the local level. Previous research focusing on this topic has usually paid no attention to the local level, and there are few studies examining the driving forces that cause school districts to unevenly implement charter school policy, while there are many studies for the effects of charter schools compared to conventional public schools. Moreover, the Colorado case addressed in this research area has never been studied, although Colorado passed its charter school legislation in 1993 and the Center for Education Reform ranks Colorado as the eighth strongest state for charter schools. It is hoped that this article will stimulate other researchers to focus on Colorado school districts' variable implementation of charter school policy.

The analysis results indicate that three predictor variables-diffusion, educational 
level, and alternative innovation-positively influence the support for charter school policy of Colorado school districts. The results of standardized coefficients shown in table 4 demonstrate that the alternative innovation variable plays the most critical role and the regional diffusion variable plays the second most important role in explaining Colorado school districts' uneven implementation of charter school policy.

Recent advancement in the diffusion literature shows that social networks developed by policy actors' frequent communication or connections have been more meaningful in enabling policy actors to formulate and implement innovative institutions than a geographical factor, following the idea of the national interaction model proposed by Gray (1973). However, this study has shown that regional diffusion is still valuable in explaining an innovative institution's implementation.

The educational level predictor variable related to socioeconomic factors supports the studies of Schneider, Teske, and Marschall (2000) and Teske, Fitzpatrick, and Kaplan (2006). Schneider and his colleagues (2000) attest that educated people take more interest in acquiring educational information than do uneducated people. Teske and his coauthors (2006) demonstrate that parents with lower socioeconomic status utilize social networks less than parents with higher socioeconomic status when they seek information about options for their children's schooling. The Colorado case supports the aforementioned scholars' arguments by proving that high educational status is a pivotal factor accounting for the likelihood of a school district implementing charter school policy.

The study demonstrates that, among the three statistically significant regressors, the variable of alternative innovation has good explanatory power for the outcome variable. This finding supports Renzulli's view that jurisdictions will be more interested in adopting and implementing educational innovations if they already have experience in adopting and implementing similar innovations. Moreover, Renzulli (2005) points out that the existence of other similar and competitive schools helps charter schools spread by letting decision makers recognize that the CPS system is not the only good system for rational consumers and that other innovative institutions can improve their students' performance. Thus, the analyzed results in this research demonstrate that Colorado is a good case that supports her logic.

In Korea, charter schools have facilitated competition in the CPS system as well since they were introduced shortly after 2000. According to the Ministry of Education Science and Technology of Korea (2010), 108 charter schools-58 public and 50 private-were in operation across Korea in 2010. These schools' core goal is to deliver more educational services to students who want to develop and promote their own talents in the Korean CPS system under uniform or top-down curricula directed by the national government. 
On the basis of the open-natural system models, this article provides Korean educational leaders who pursue innovations and reforms with an implication from a statistical result - there is a positive relationship between alternative innovations and Colorado school districts' implementation of charter school policy. In the case of Korea, change in the CPS system is at the early stage, and many citizens are unfamiliar with the concept of school choice. That means that Korean citizens are usually not familiar with new innovative tools for changing the CPS system. If educational leaders want to change the Korean CPS system, they need to actively introduce more innovative tools to Korean citizens through the mass media or public hearings so that citizens can be embedded in the effect and legitimacy of innovative tools. That is why their embeddedness to new tools for innovation will help citizens support innovative education policies from governments that strive to change the Korean CPS system.

A limitation of this study is that it has not sufficiently measured the alternative innovation variable. It seems that using alternative schools as the only proxy is not enough to measure the alternative innovation variable. If future studies add other innovations - such as magnet schools or private schools - as proxies for alternative innovation, they will be able to more concretely account for the variance in Colorado school districts' implementation of charter school policy.

Additionally, it will be good to test the role of networked diffusion among policy actors, especially school districts and outside organizations. Like Gray (1973), Rogers (2003) indicates that innovative institutions' adoption and implementation by policy actors occur more frequently because they imitate other policy actors' institutions through contact and communication over time. He argues that "the heart of the diffusion process consists of the modeling and imitation by potential adopters of their network partners who have adopted previously" (p. 18). Rogers's view supports that reflecting Gray's idea is reasonable on studies relevant to innovative institutions' adoption and implementation. Literature review vividly points out that Colorado currently has 12 public and nonprofit organizations working for educational innovations and reforms. Therefore, it is possible for future studies to test whether school districts that have strong networks with other organizations are more likely to implement a charter school policy. 


\section{REFERENCES}

Basilico, E., Broggini, P., Eder, I., \& Truax, K. 2002. Teacher's salaries in Colorado: Reasons, consequences, alternative for below average compensation. http://www .centerfortaxpolicy. org/reports/02-teachers_salaries.pdf.

Berry, F. S., \& Berry, W. D. 1990. State lottery adoptions as policy innovations: An event history analysis. American Political Science Review, 84(2): 395-413. . 1999. Innovation and diffusion models in policy research. In P. Sabatier (ed.), Theories of the policy process (pp. 169-200). Boulder, CO: Westview Press.

2007. Innovation and diffusion models in policy research. In P. Sabatier (ed.), Theories of the policy process (2nd ed.) (pp. 223-260). Boulder, CO: Westview Press.

Buchanan, J. M., \& Tullock, G. 1962. The calculus of consent. Ann Arbor, MI: University of Michigan Press.

Buckley, J., \& Schneider, M. 2007. Charter schools: Hope or hype? Princeton, NJ: Princeton University Press.

Buddin, R., \& Zimmer, R. 2005. Student achievement in charter school: A complex picture. Journal of Policy Analysis and Management, 24(2): 351-371.

Carpenter, D. M., \& Kafer, K. 2009. A typology of Colorado charter schools. Denver, CO: Colorado Department of Education. http://www.cde.state.co.us/cdechart/ download/ typologyreport_012709.pdf.

Carver, P. R., Lewis, L., \& Tice, P. 2010. Alternative schools and programs for public school students at risk of education failure: 2007-08. Washington, DC: National Center for Education Statistics, Institute of Education Sciences, US Department of Education. http://nces.ed.gov/pubs2010/2010026.pdf.

Center for Education Reform. 2006. Charter schools: Today. Changing the face of American education. Washington, DC: http://heartland.org/sites/all/modules/ custom/heartland_migration/files/pdfs/20766.pdf.

Chubb, J. E., \& Moe, T. 1990. Politics, markets, and the organization of schools. Washington, DC: Brookings Institution.

Colorado Department of Education. 2007. Summary of school district data for school year 2006-2007. Denver, CO: http://www.cde.state.co.us/cdereval/download/ PDF/20062007SummaryofSchool DistrictData.pdf.

DiMaggio, P. J., \& Powell, W. W. 1983. The iron cage revisited: Institutional isomorphism and collective rationality in organizational fields. American Sociological Review, 48(2): 147-160.

Frederickson, G. H., Johnson, G., \& Wood, C. H. 2004. The adapted city: Institutional 
dynamics and structural change. Armonk, NY: M. E. Sharp.

Gray, V. 1973. Innovation in the states: A diffusion study. American Political Science Review, 67(4): 1174-1185.

Gurantz, O. 2010. The academic progress of alternative school students transitioning into comprehensive high schools. Stanford, CA: John W. Gardner Center for Youth and Their Communities. http://gardnercenter.stanford.edu/resources/ publicatons/JGC_IB_AlternativeSchoolStudentsTransition2010.pdf.

Hess, F. M. 2008. The future of educational entrepreneurship: Possibilities for school reform. Cambridge, MA: Harvard Education Press.

Hill, E. G. 2007. Improving alternative education in California. Sacramento, CA: The Legislative Analyst's Office. http://www.cpec.ca.gov/CompleteReports/External Documents/LAO_alt_ed_020707.pdf.

Hodge, G. A. 2000. Privatization: An international review of performance. Boulder, CO: Westview Press.

Julnes, P., \& Holzer, M. 2001. Promoting the utilization of performance measures in public organizations: An empirical study of factors affecting adoption and implementation. Public Administration Review, 61(6): 693-708.

Kirst, M. W. 2007. Politics of charter schools: Competing national advocacy coalitions meet local politics. Peabody Journal of Education, 82(2-3): 184-203.

Klingner, D. E. 2006. Diffusion and adoption of innovations: A development perspective. In United Nations Department of Economic and Social Affairs (ed.), Innovations in governance and public administration: Replicating what works (pp. 61-66). New York: United Nations.

Landry, R., Lamari, M., \& Amara, N. 2003. The extent and determinants of the utilization of university research in government agencies. Public Administration Review, 63(2): 192-205.

Lee, J., \& Kim, S. 2010. Determinants of charter school policy adoption in U.S. states: A case study of Colorado school districts. International Review of Public Administration, 15(2): 29-44.

Leech, N. L., Barrett, K. C., \& Morgan, G. A. 2008. SPSS for intermediate statistics: Use and interpretation. Mahwah, NJ: Erlbaum.

Mazmanian, D. A., \& Sabatier, P. A. 1980. A multivariate model of public policy-making. American Journal of Political Science, 24(3): 439-468.

McGuinn, P. 2003. Breaking open the iron triangle-interest groups, public opinion, and federal education policy. Paper presented to the 2003 Northeastern Political Science Association Conference.

Meyer, J. W., \& Rowan, B. 1977. Institutionalized organizations: Formal structure as myth and ceremony. American Journal of Sociology, 83(2): 340-363. 
Ministry of Education Science and Technology of Korea. 2010. Happy images with autonomous high schools. Seoul, Korea: http://www.mest.go.kr/web/279/ko/ board/view.do?bbsId= 45\&\&boardSeq=18271\&mode=view.

Mintrom, M. 1997. Policy entrepreneurs and the diffusion of innovation. American Journal of Political Science, 41(3): 738-770.

2000. Policy entrepreneurs and school choice. Washington, DC: Georgetown University Press.

Mintrom, M., \& Vergari, S. 1997. Education reform and accountability issues in an intergovernmental context. Publius, 27(2): 143-166.

1998. Policy networks and innovation diffusion: The case of state education reforms. Journal of Politics, 60(1): 126-148.

Ostrom, E. 1999. Institutional rational choice: An assessment of the institutional analysis and development framework. In P. Sabatier (ed.), Theories of the policy process (pp. 35-71). Boulder, CO: Westview Press.

2007. Institutional rational choice: An assessment of the institutional analysis and development framework. In P. Sabatier (ed.), Theories of the policy process (2nd ed.) (pp. 21-64). Boulder, CO: Westview Press.

Portz, J. 1996. Problem definition and policy agendas: Shaping the education agenda in Boston. Policy Studies Journal, 24(3): 371-386.

Powell, W. W., \& DiMaggio, P. J. 1991. The new institutionalism in organizational analysis. Chicago, IL: University of Chicago Press.

Rainey, H. 2003. Understanding and managing public organizations (3rd ed.). San Francisco, CA: Jossey-Bass.

Renzulli, L. A. 2005. Organizational environments and the emergence of charter schools in the United States. Sociology of Education, 78(January): 1-26.

Renzulli, L. A., \& Roscigno, V. J. 2005. Charter school policy, implementation, and diffusion across the United States. Sociology of Education, 78(October): 344-366. 2007. Charter schools and the public good. Contexts, 6(1): 31-36.

Rivera, J., \& deLeon, P. 2004. Is greener whiter? voluntary environmental performance of western ski areas. Policy Studies Journal, 32(3): 417-437.

Rivera, J., deLeon, P., \& Koerber, C. 2006. Is greener whiter yet? The sustainable slopes program after five years. Policy Studies Journal, 34(2): 195-221.

Rogers, E. M. 1962. Diffusion of innovation. New York: Free Press. 2003. Diffusion of innovation (5th ed.). New York: Free Press.

Schneider, M., Teske, P., \& Marschall, M. 2000. Choosing schools: Consumer choice and the quality of American schools. Princeton, NJ: Princeton University Press.

Scott, R. W. 1998. Organizations: Rational, natural, and open systems (4th ed.). Upper Saddle River, NJ: Prentice-Hall. 
Stoddard, C., \& Corcoran, S. P. 2007. The political economy of school choice: Support for charter schools across states and school districts. Journal of Urban Economics, 62(1): 27-54.

Teske, P., Fitzpatrick, J., \& Kaplan, G. 2006. The information gap? Review of Policy Research, 23(5): 969-981.

Vergari, S. 1999. Charter schools: A primer on the issues. Education and Urban Society, 31(4): 389-405. . 2002. The charter school landscape. Pittsburgh, PA: University of Pittsburgh Press.

. 2007. The politics of charter schools. Educational Policy, 21(1): 15-39.

Walker, J. L. 1969. The diffusion of innovations among the American states. American Political Science Review, 63(3): 880-899.

1981. The diffusion of knowledge, policy communities and agenda setting: The relationship of knowledge and power. In J. E. Tropman, M. J. Dluhy, \& R. M. Lind (eds.), New strategic perspectives on social policy (pp. 75-96). New York: Pergamon Press.

Webber, D. 1987. Legislators' use of policy information. American Behavioral Scientist, 30(6): 612-631.

Weimer, D. L., \& Vining, A. R. 1999. Policy analysis: Concepts and practice. Upper Saddle River, NJ: Prentice Hall. 2005. Policy analysis: Concepts and practice (4th ed.). Upper Saddle River, NJ: Prentice Hall.

Wong, K. K., \& Langevin, W. E. 2007. Policy expansion of school choice in the American states. Peabody Journal of Education, 82(2-3): 440-472.

Wong, K. K., \& Shen, F. X. 2002. Politics of state-led reform in education: Market competition and electoral dynamics. Educational Policy, 16(1): 161-192.

Ziebarth, T. 2005. Peaks and valleys: Colorado's charter school landscape. Washington, DC: Progressive Policy Institute. http://www.dlc.org/documents/Colorado_ Charter_1220.pdf. 